\title{
PENGEMBANGAN BUKU SISWA FISIKA BERBASIS KEARIFAN LOKAL (MAJA LABO DAHU) DI MAN 1 KOTA BIMA
}

\section{DEVELOPMENT OF PHYSICAL STUDENT BOOKS BASED ON LOCAL INTEREST (MAJA LABO DAHU) IN MAN 1 CITY OF BIMA}

\author{
${ }^{1)}$ Atabikrifki, ${ }^{2)}$ M. Agus Martawijaya, ${ }^{3)}$ Jasruddin \\ Universitas Negeri Makassar \\ Kampus UNM Parangtambung Jln. Daeng Tata Raya, Makassar, 90224 \\ 1)e-mail : Atabikrifki27@gmail.com
}

\begin{abstract}
Pengembangan Buku Siswa Fisika Berbasis Kearifan Lokal (Maja Labo Dahu) Di Man 1 Kota Bima. Penelitian ini merupakan penelitian pengembangan (Research and Development) dengan uji coba terbatas yang bertujuan untuk mengembangkan buku fisika berbasis kearifan lokal siswa (maja labo dahu). Subjek penelitian ini adalah siswa kelas $\mathrm{X}$ MIA2 di MAN 1 Kota Bima. Model pengembangan yang digunakan dalam penelitian ini adalah model Thiagarajan atau model 4-D yang meliputi empat tahap, yaitu fase Tentukan, Desain, Pengembangan dan Pengembangan, tetapi dalam penelitian ini fase penyebaran tidak dilakukan karena hanya uji coba terbatas. Buku siswa Fisika berdasarkan kearifan lokal (maja labo dahu) telah divalidasi dan telah direvisi sehingga dinyatakan valid dan dapat digunakan. Hasil uji coba terbatas menunjukkan bahwa buku siswa fisika berdasarkan kearifan lokal (maja labo dahu) berada dalam kriteria yang sangat baik dengan persentase $85,9 \%$ oleh pendidik dan berada pada kriteria mudah dipahami dengan persentase $87,7 \%$ oleh siswa.
\end{abstract}

Kata kunci: Buku Pelajar Fisika, Kearifan Lokal (Maja labo Dahu)

\begin{abstract}
Development Of Physical Student Books Based On Local Interest (Maja Labo Dahu) In Man 1 City Of Bima. This research is a development research (Research and Development) with a limited trial which aims to develop a book of physics based local wisdom students (maja labo dahu). The subjects of this study were students of class X MIA2 in MAN 1 Bima City. The development model used in this study is the Thiagarajan model or 4-D model which includes four stages, namely the Define phase, the Design, Development and Development Phase, but in this study the deployment phase was not carried out because it was only a limited trial. The book of Physics students based on local wisdom (maja labo dahu) has been validated and has been revised so that it is declared valid and can be used. The results of the limited trial showed that physics students' books based on local wisdom (maja labo dahu) were in very good criteria with a percentage of $85.9 \%$ by educators and were on the criteria of being easily understood with a percentage of $87.7 \%$ by students.
\end{abstract}

Keywords : Physics Student Book, Local Wisdom (Maja labo Dahu).

\section{PENDAHULUAN}

Kemendikbud menyebut kearifan

lokal dengan istilah keunggulan lokal, selain itu pembelajaran berbasis keunggulan lokal memiliki beberapa landasan yuridis diantaranya adalah Peraturan Pemerintah Nomor 19 tahun 2005

BAB III pasal 14 ayat 1 menyatakan bahwa "Untuk SMA/MA/SMALB atau bentuk lain yang sederajat dapat memasukan pendidikan 
berbasis keunggulan lokal. Peraturan Pemerintah Nomor 17 Tahun 2010 pasal 35 ayat 2, bahwa "Pemerintah kabupaten/Kota melaksanakan dan/atau memfasilitasi perintisan program dan/atau satuan pendidikan yang sudah atau hampir memenuhi Standar Nasional Pendidikan untuk dikembangkan menjadi program dan/atau satuan pendidikan bertaraf internasional dan/atau berbasis keunggulan lokal".

Dengan adanya Pendidikan berbasis keunggulan lokal, diharapkan semua peserta didik yang berada di suatu wilayah tertentu dapat memahami sains dan mengaplikasikan pembelajaran yang mereka dapati di sekolah dalam kehidupan sehari-hari. Jika dikaitkan dengan salah satu mata pelajaran sekolah yaitu sains, maka indikator-indikator yang telah disebutkan di atas dapat dijadikan sebagai dasar pengembangan indikator dalam pelajaran sains yang tertuang dalam buku pelengkap sains berbasis kearifan lokal. Sains merupakan suatu ilmu yang mempelajari gejala-gejala alam yang ada disekitar. Dalam pembagiannya, Sains terbagi menjadi beberapa bagian yaitu Fisika, Kimia dan Biologi. Ilmu Fisika merupakan ilmu yang sangat menarik untuk dikaji karena ilmu fisika adalah ilmu yang mempelajari gejala alam.

Kota Bima merupakan sebuah kota yang memiliki wilayah strategis, hal ini dikarenakan kota Bima adalah satu-satunya kota yang ada di pulau Sumbawa. Kota Bima kebanyakan merupakan warga pendatang dari berbagai daerah. Oleh karena itu kearifan lokal Kota Bima yang di kenal dengan istilah "Maja Labo Dahu" harus dilestarikan ditengah-tengah masyarakatnya yang beragam. Dalam hal ini khususnya bidang sains, Kearifan lokal sangatlah menarik untuk dikaji diantaranya adalah potensi-potensi daerah yang dimiliki kota Bima seperti kerajinan-kerajinan yang berbahan dasar dari alam sekitar. Selain dari pada itu berdasarkan hasil wawancara dengan tokoh masyarakat bahwa betul adanya terjadi kondisi dimana kearifan lokal Bima yang di kenal dengan istilah "Maja Labo Dahu" telah mengalami kekhawatiran karena kondisi dan sikap peserta didik zaman sekarang yang kurang mencerminkan nilai dari kearifan lokal tersebut sehingga bagaimana hal tersebut bisa di tanamkan kembali ke peserta didik, misalnya alasan penting di balik pilihan rimpu yang pada saat itu sebagai pertanda bahwa ia adalah muslim sejati di mbojo, pilihan rimpu tidak terlepas dari nilai-nilai keislaman di mbojo dan pilihan itu di dukung dengan semboyan daerah Bima yang berbunyi "Maja Labo Dahu" yang berarti Maja adalah malu dan Dahu adalah takut, yang berarti malu dan takut jika menggumbar aurat di depan publik atau umum. "Maja Labo Dahu" yang sebetulnya menjadi alat kontrol bagi setiap warga Bima dalam bertindak, baik secara horisontal (bertindak sesama manusia) maupun secara vertikal (hubungan dengan Tuhan). Oleh karena itu harapan dari 
masyarakat bagaimana kearifan lokal (maja labo dahu) bisa dilestarikan kembali.

Berdasarkan latar belakang di atas, maka peneliti mengangkat penelitian dengan judul: Pengembangan Buku Siswa Fisika Berbasis Kearifan Lokal (Maja Labo Dahu) di MAN 1 Kota Bima. Produk yang dihasilkan diujicobakan pada peserta didik kelas X MIA2 di MAN 1 Kota Bima.

\section{METODE}

\section{A. Jenis Penelitian}

Penelitian ini termasuk jenis $R \& D$ (research and development) (Sugiyono, 2013) Penelitian ini menggunakan pengembangan Model 4-D (Four-D Model) yang dikembangkan oleh S.Thiagarajan, meliputi tahap pendefenisian (Define), tahap perencanaan (Design), tahap pengembangan (Develop), dan tahap penyebaran (Disseminate). Dimana dalam penelitian ini peneliti membatasi hanya sampai pada tahap pengembangan yang kemudian uji coba terbatas.

\section{B. Waktu dan Tempat Penelitian}

Penelitian ini terdiri atas beberapa tahapan, diawali dengan berbagai analisis mendasar yang dibutuhkan untuk mengembangkan bahan ajar, meliputi kondisi subjek dan sasaran penelitian serta materi yang sesuai dengan bahan ajar yang dikembangkan melalui analisis kurikulum yang digunakan di tempat penelitian pada bulan Desember 2017.

\section{Subjek Coba}

Subjek coba pada penelitian ini adalah peserta didik kelas X MIA2 MAN 1 Kota Bima.

\section{Instrumen dan Perangkat}

Perangkat yang dikembangkan dalam penelitian ini adalah bahan ajar yang berupa buku peserta didik yang sifatnya sebagai pelengkap dan barbasis kearifan lokal (maja labo dahu). Buku siswa ini berisi informasi dan wawasan tentang beberapa kearifan lokal maja labo dahu dan di tambah dengan proses kerajinan yang ada di daerah Bima. Buku siswa dibatasi pada materi Hukum Newton.

Adapun instrumen penelitian yang digunakan dalam penelitian ini sebagai berikut:

1. Lembar validasi

2. Lembar persepsi praktisi/pendidik

3. Tes rumpang

\section{E. Prosedur Penelitian}

Berikut merupakan gambaran dari alur prosedur dalam penelitian desain 4-D yang dikembangkan oleh S.Thiagarajan yang telah di modifikasi oleh peneliti sebagai berikut ini: 



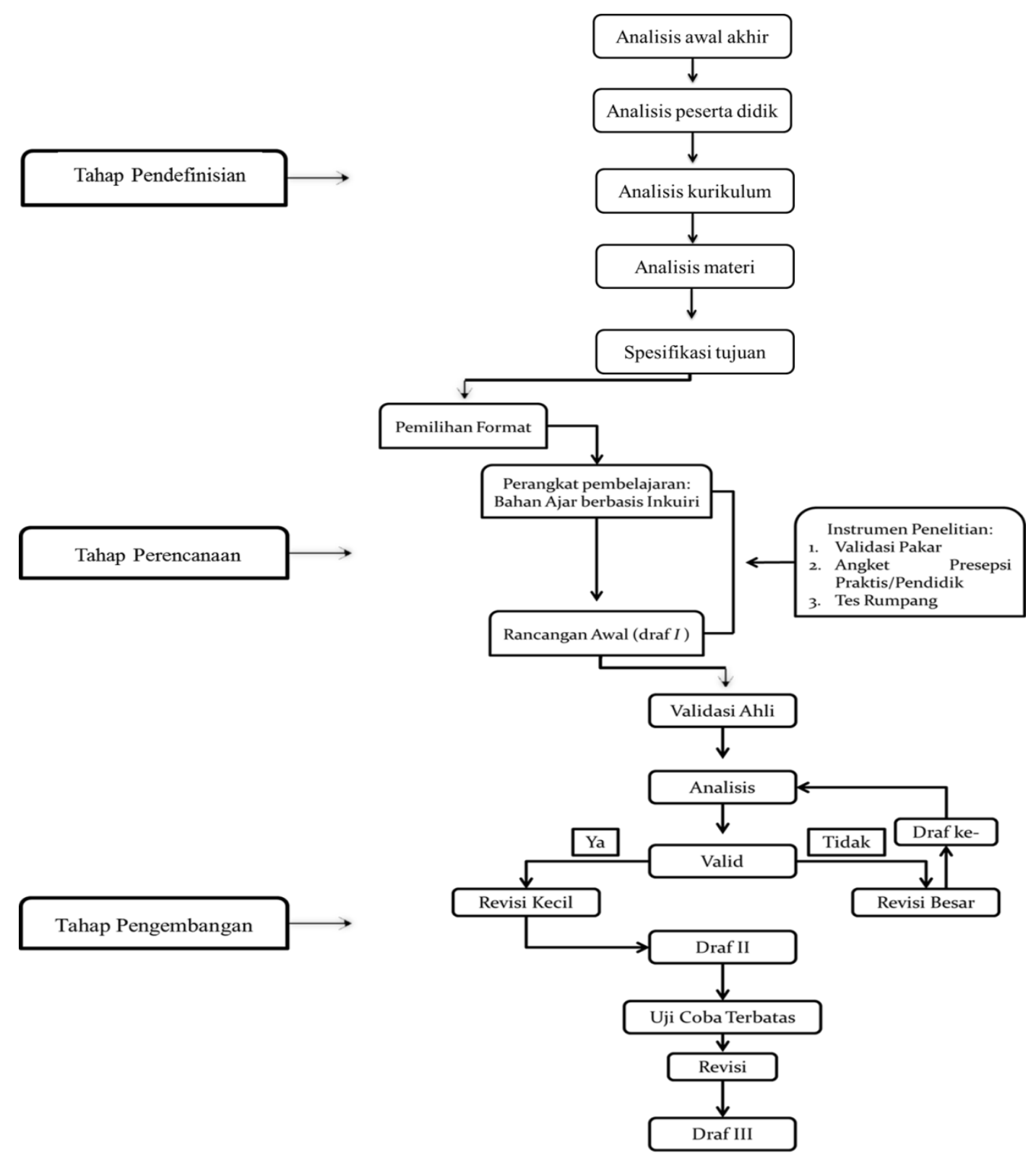




\section{HASIL DAN PEMBAHASAN}

\section{A. Hasil Penelitian}

Berikut ini dijelaskan hasil penelitian pengembangan bahan ajar fisika peserta didik berbasis kearifan lokal sebagai penunjang pembelajaran.

Analisis Validasi Bahan Ajar oleh Ahli Pakar

- Untuk uji Gregory

Tabel 1. Uji Gregory Validasi Bahan Ajar

\begin{tabular}{cccc}
\hline Kriteria & \multicolumn{2}{c}{ Ahli Pakar } & \\
\cline { 2 - 3 } Penilaian & $\mathbf{1}$ & $\mathbf{2}$ & Hasil \\
\hline $\mathbf{1}$ & 3 & 3 & $\mathrm{D}$ \\
$\mathbf{2}$ & 3 & 4 & $\mathrm{D}$ \\
$\mathbf{3}$ & 3 & 4 & $\mathrm{D}$ \\
$\mathbf{4}$ & 3 & 4 & $\mathrm{D}$ \\
$\mathbf{5}$ & 3 & 3 & $\mathrm{D}$ \\
$\mathbf{6}$ & 3 & 3 & $\mathrm{D}$ \\
$\mathbf{7}$ & 2 & 3 & $\mathrm{C}$ \\
$\mathbf{8}$ & 3 & 3 & $\mathrm{D}$ \\
$\mathbf{9}$ & 3 & 4 & $\mathrm{D}$ \\
$\mathbf{1 0}$ & 3 & 4 & $\mathrm{D}$ \\
$\mathbf{1 1}$ & 3 & 4 & $\mathrm{D}$ \\
$\mathbf{1 2}$ & 3 & 3 & $\mathrm{D}$ \\
$\mathbf{1 3}$ & 3 & 4 & $\mathrm{D}$ \\
$\mathbf{1 4}$ & 3 & 4 & $\mathrm{D}$ \\
$\mathbf{1 5}$ & 3 & 4 & $\mathrm{D}$ \\
$\mathbf{1 6}$ & 3 & 4 & $\mathrm{D}$ \\
$\mathbf{1 7}$ & 3 & 4 & $\mathrm{D}$ \\
\hline
\end{tabular}

$$
\begin{gathered}
V_{c}=\frac{D}{A+B+C+D} \\
V_{c}=\frac{16}{17} \\
V_{c}=0,94
\end{gathered}
$$

Selain itu dianalisis pula kriteria interpretasi validasi ahli terhadap bahan ajar berbasis Kearifan lokal. Pada lembar validasi, para ahli diminta untuk memberikan skor pada setiap pernyataan dengan ketentuan skor 4(sangat baik), 3(baik), 2(kurang baik), 1(tidak baik). Peneliti mendapatkan bahwa untuk masing- masing aspek yang dinilai pada bahan ajar berupa buku bacaan adalah sebagai berikut:

Tabel 2. Persentase Interperetasi Validasi Ahli

\begin{tabular}{clr}
\hline No & Aspek & $\begin{array}{r}\text { Rata-rata } \\
(\%)\end{array}$ \\
\hline 1 & $\begin{array}{l}\text { Kelayakan Isi } \\
\text { Kelayakan } \\
\text { penyajian } \\
\text { Kelayakan } \\
\text { kebahasaan }\end{array}$ & 851.25 \\
3 & 87.5 \\
\hline
\end{tabular}

Adapun analisis selengkapnya sebagai berikut :

- Hasil dari Validasi Ahli, tanggapan ahli

Tabel 3. Aspek Kelayakan Isi

\begin{tabular}{|c|c|c|c|c|c|}
\hline \multirow{3}{*}{$\begin{array}{c}\text { PERNYA } \\
\text { TAAN }\end{array}$} & \multicolumn{2}{|c|}{ RESPON } & \multirow{2}{*}{$\begin{array}{c}\text { SKO } \\
\text { R }\end{array}$} & \multirow{2}{*}{$\begin{array}{l}\text { SK } \\
\text { OR }\end{array}$} & \multirow{3}{*}{$\begin{array}{c}\text { PERSEN } \\
\text { TASE } \\
(\%)\end{array}$} \\
\hline & DE & & & & \\
\hline & 1 & 2 & AL & $\mathrm{X}$ & \\
\hline 6 & 3 & 3 & 6 & 8 & 75 \\
\hline 7 & 2 & 3 & 5 & 8 & 62.5 \\
\hline 8 & 3 & 3 & 6 & 8 & 75 \\
\hline 9 & 3 & 4 & 7 & 8 & 87.5 \\
\hline 10 & 3 & 4 & 7 & 8 & 87.5 \\
\hline 11 & 3 & 4 & 7 & 8 & 87.5 \\
\hline 12 & 3 & 3 & 6 & 8 & 75 \\
\hline 13 & 3 & 4 & 7 & 8 & 87.5 \\
\hline 14 & 3 & 4 & 7 & 8 & 87.5 \\
\hline
\end{tabular}

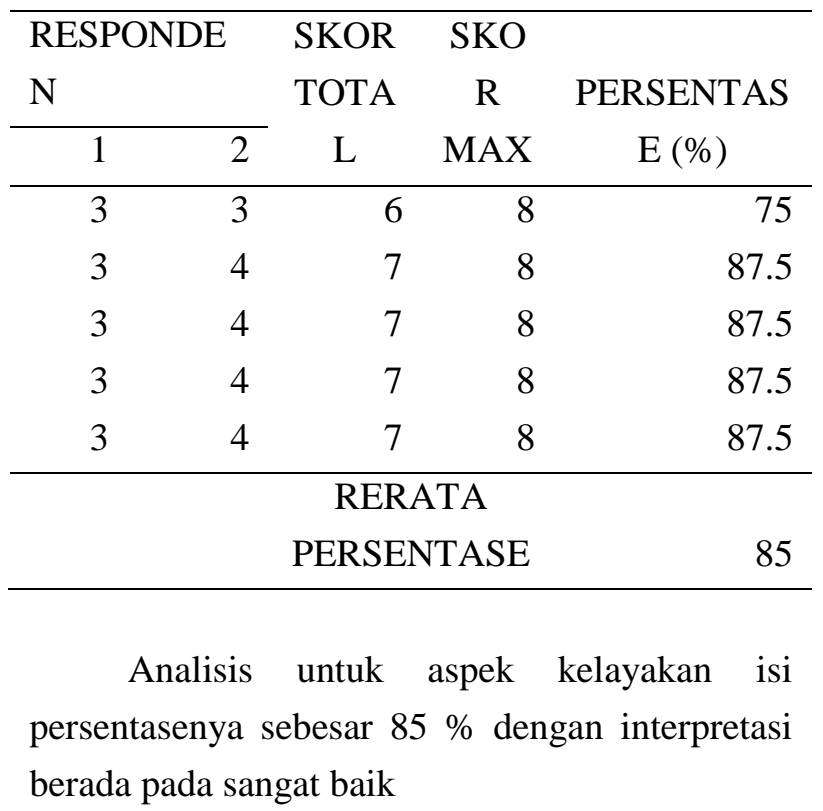

Tabel 4. Aspek Kelayakan Penyajian 


\begin{tabular}{|c|c|c|c|c|}
\hline 15 & 3 & 4 & 8 & 87.5 \\
\hline \multicolumn{5}{|c|}{ RERATA } \\
\hline \multicolumn{5}{|c|}{ PERSENT } \\
\hline & & & ASE & 81.25 \\
\hline
\end{tabular}

Analisis untuk aspek kelayakan penyajian persentasenya sebesar $81,25 \%$ dengan interpretasi berada pada kriteria sangat baik

1) Hasil validasi lembar persepsi
praktisi/pendidik

Hasil validasi lembar presepsi praktiksi/pendidik dilihat dari aspek petunjuk, isi dan bahasa menggunakan analisis formula Gregory. Adapun hasil yang diperoleh untuk ketiga aspek yang menjadi kriteria kelayakan instrumen diperoleh nilai content validity $\left(\mathrm{V}_{\mathrm{c}}\right)$ sebesar 1 atau $100 \%$. Hal ini menunjukkan lembar persepsi praktisi/pendidik valid atau dapat digunakan.

a. Hasil ujicoba

1) Persepsi praktisi/pendidik

Pengukuran presepsi praktisi/ pendidik menggunakan instrument berupa lembar pernyataan untuk memperoleh presepsi praktisi/pendidik terhadap bahan ajar fisika yang dikembangkan. Persentase rata-rata presepsi praktisi/pendidik untuk tiga aspek kelayakan sebesar $85,9 \%$.

Tabel 5. Persentase Masing-Masing Aspek

\begin{tabular}{clc}
\hline & & $\begin{array}{c}\text { Rata- } \\
\text { rata } \\
\%\end{array}$ \\
No & Aspek & 84.5 \\
\hline 1 & Kelayakan Isi & 87.5 \\
2 & Kelayakan penyajian & 92.0 \\
3 & Kelayakan kebahasaan & 92.9 \\
\hline \multicolumn{2}{l}{ Rerata } & 85.9 \\
\hline
\end{tabular}

2) Tingkat keterbacaan peserta didik

Pengukuran Tingkat keteracaan peserta didik terhadap Bahan Ajar Fisika berupa buku bacaan menggunakan tes rumpang. Hasil tes rumpang peserta didik berada pada persentase $87,7 \%$. Hal ini menunjukkan bahan ajar fisika mudah dipahami oleh peserta didik sebagai responden dari tes rumpang yang telah dilakukan oleh peneliti.

\section{B. Pembahasan Hasil Penelitian}

Berikut merupakan pembahasan dari hasil penelitian yang telah dilakukan oleh peneliti sesuai dengan tujuan penelitian yaitu mendeskripsikan bahan ajar fisika berbasis Kearifan lokal. Mengetahui persepsi praktisi/pendidik dan tingkat keterbacaan peserat didik.

Dari hasil validasi menunjukkan bahwa bahan ajar yang dikembangkan dinyatakan valid atau dapat diujicobakan setelah perbaikan bahan ajar, dengan validitas isi $\left(\mathrm{V}_{\mathrm{c}}\right)$ sebesar $94 \%$ berada di atas $75 \%$.

Bahan ajar ini dianggap praktis jika kategori persepsi praktisi atau pendidik sekurang kurangnya berada dalam kategori baik. Persepsi yang diberikan oleh praktisi/pendidik sangat penting dalam menilai sebuah bahan ajar fisika yang berupa buku bacaan. Hal ini, karena pendidik telah berpengalaman dalam menggunakan buku bacaan dalam proses belajar dan mengajar.

Sebelum instrumen presepsi praktisi/pendidik diujicobakan, terlebih dahulu dilakukan validasi pakar untuk lembar persepsi praktisi. Berdasarkan penilaian validator menunjukkan bahwa lembar persepsi praktisi/pendidik valid dengan validitas isi $\left(\mathrm{V}_{\mathrm{c}}\right)$ sebesar $100 \%$ berada diatas $75 \%$. Sehingga dapat disimpulkan bahwa instrumen tersebut layak digunakan untuk mengukur presepsi praktisi/pendidik terhadap bahan ajar fisika berbasis Kearifan lokal.

Selanjutnya dilakukan ujicoba terbatas untuk memperoleh data tentang presepsi praktisi/pendidik terhadap bahan ajar fisika berbasis kearifan lokal, pada tahap ini dilibatkan 3 pendidik. Setelah dilakukan pengukuran presepsi praktisi/pendidik, diperoleh rata-rata 
persentase sebesar $85,9 \%$ untuk seluruh aspek yang dinilai. Sesuai dengan kriteria interpretasi sko $r$ yang dijadikan acuan, presepsi praktisi/pendidik terhadap buku bacaan fisika berbasis Kearifan lokal berada dalam kriteria sangat baik.

Hasil analisis menunjukkan bahwa tingkat keterbacaan bahan ajar yang dibuat berdasarkan hasil tes rumpangdiperoleh $87,7 \%$. Hal ini menunjukkan bahwa bahan ajar ini telah memenuhi standar tingkat keterbacaan minimal yaitu $60 \%$, berarti bahan ajar ini dapat disimpulkan mudah dipahami oleh peserta didik.

\section{SIMPULAN}

Berdasarkan penelitian yang telah dilakukan dapat disimpulkan sebagai berikut:

1. Bahan ajar berbasis Kearifan lokal (maja labo dahu) sebagai penunjang pelaksanaan Pembelajaran di MAN 1 Kota Bima yang layak digunakan oleh ahli pakar dengan materi Hukum Newton berada pada contents validity 0,94 . Profil bahan yang dikatakan layak yaitu buku bacaan berbasis Kearifan lokal mengarahkan peserta didik untuk mempelajari kearifan lokal setempat.

2. Persepsi praktisi/pendidik terhadap bahan ajar fisika berbasis Kearifan lokal (maja labo dahu) sebagai penunjang pelaksanaan pembelajaran berupa buku bacaan, peserta didik berada pada kriteria sangat baik dengan aspek yang dinilai adalah

3. kelayakan isi, kelayakan penyajian dan kelayakan kebahasaan.

Keterbacaan peserta didik terhadap bahan ajar fisika berbasis Kearifan lokal (maja labo dahu) berada pada kriteria bahan ajar yang mudah dipahami oleh peserta didik.

\section{DAFTAR RUJUKAN}

Kemendikbud. 2014. Pembelajaran pada pendidikan dasar dan pendidikan menengah. Jakarta: Mentri Pendidikan dan Kebudayaan.

Kemendikbud. 2016. Peraturan Menteri Pendidikan dan Kebudayaan Republik Indonsesia Nomor 22 Tahun 2016 Tentang Standar Proses Pendidikan Dasar dan Menengah. Jakarta: Mentri Pendidikan dan Kebudayaan

Sugiyono. 2013. Metode Penelitian Pendidikan Pendekatan Kuantitatif Kualitatif dan $R$ $\& D$. Bandung: Alfabeta. 